\title{
XLVIII. On the invention and first introduction of Mr. Kœnig's printing machine
}

\section{Richard Taylor F.S.A.}

To cite this article: Richard Taylor F.S.A. (1847) XLVIII. On the invention and first introduction of Mr. Kœnig's printing machine, Philosophical Magazine Series 3, 31:208, 297-301, DOI: $10.1080 / 14786444708562645$

To link to this article: http://dx.doi.org/10.1080/14786444708562645

曲 Published online: 30 Apr 2009.

Submit your article to this journal $₫$

Џ Article views: 2

Q View related articles $₫$ 


\section{[ 297 ]}

XLVIII. On the Invention and First Introduction of $\mathrm{Mr}$. Kœnig's Printing Machine. By RICHa RD TaYLor, F.S. A.\&c.

"As a step in the progress of civilization the Steam Press can only be compared to the original discovery of Printing itself."-Times Newspaper, $J u b y 29,1847$, on the death of Mr. $J$. Walter.

WORE than a century after its introduction the first inven11 tion of the Art of Printing became a subject of long-continued controversy, remarkable for the insufficiency and fallacy of the most confident assertions resting upon pretended traditions and unsupported conjectures. And, as Hadrian Junius in 1575 first disputed the claims of Gutemberg after so long a period had elapsed, so did Atkyns as late as 1664 first deny the title of Caxton to the honour of having introduced the art into our own country. Hence one of the writers in this controversy remarks that "the Art of Printing, which has given light to most other things, hides its own head in darkness."

It will be our own fault if we allow any unfounded assertions and pretensions to obtain currency with regard to an improvement in the art, of which The Times newspaper has said that "from the days of Faust and Gutemberg to the present hour there has been only one great revolution in the art of printing, and it occurred in the year 1814. Of that revolution Mr. Walter was the prominent and leading agent."

Now though I would on no account detract from the general merits of the late Mr. Walter, as set forth in the Obituary and extended Memoir which appeared in The Times of the 29th of July and 16th of September, yet I cannot allow the representations which are made in these articles, as to any share which he is alleged to have had in this important invention, to pass without the most unqualified contradiction.

In the Obituary we read as follows :-

"But one achievement alone is sufficient to place Mr. Walter high in that list which the world, as it grows older and wiser, will more and more appreciate-

'Inventas aut qui vitam excoluere per artes,

Quique sui memores alios fecere merendo.'

He first brought the steam-engine to the assistance of the public press. Familiar as the discovery is now, there was a time when it seemed fraught with difficulties as great as those which Fulton has overcome on one element and Stephenson on another. To take off 5000 impressions in an hour was once as ridiculous a conception as to paddle a ship fifteen miles against wind and tide, or to drag in that time a train of carriages weighing 100 tons fifty miles. Mr. Walter, who, without being a visionary, may be said to have thought nothing impossible that was useful and good, was early resolved that there should be no impossibility in printing by steam. It took a long time in those days to strike off the 3000 or 4000 copies of The 


\section{$298 \mathrm{Mr}$. R. Taylor on the Invention and First Introduction}

Times. Mr. Walter could not brook the tædium of the manual process. As early as the year 1804 an ingenious compositor, named Thomas Martyn, had invented a self-acting machine for working the press, and had produced a model which satisfied Mr. Walter of the feasibility of the scheme. Being assisted by Mr. Walter with the necessary funds, he made considerable progress towards the completion of his work."

"On the very eve of success he was doomed to bitter disappointment. He had exhausted his own funds in the attempt, and his father, who had hitherto assisted him, became disheartened, and refused him any further aid. The project was therefore for the time abandoned." [Why abandoned, we may ask, if so feasible, and on the very eve of success?]

"Mr. Walter, however, was not the man to be deterred from what he had once resolved to do. He gave his mind incessantly to the subject, and courted aid from all quarters, with his usual munificence. In the year 1814 he was induced by a clerical friend, in whose judgement he confided, to make a fresh experiment; and accordingly the machinery of the amiable and ingenious Kœnig, assisted by his young friend Bauer, was introduced-not, indeed, at first, into The Times office, but into the adjoining premises, such caution being thought necessary from the threatened violence of the pressmen. Here the work advanced, under the frequent inspection and advice of the friend alluded to. At one period these two able mechanics suspended their anxious toil, and left the premises in disgust. After the lapse, however, of about three days, the same gentleman discovered their retreat*, induced them to return, showed them to their surprise their difficulty conquered, and the work still in progress."

Who would not infer from the above, that Mr. Walter, having determined "to make a fresh experiment," in pursuance of those which he had long before abandoned (notwithstanding his early resolution that there should be no impossibility in it), and " courting aid from all quarters with his usual munificence," had been actually the person that enabled Mr. Koenig to pursue his labours on Mr. Walter's premises, "under the inspection and advice of Mr. Walter's clerical friend," and thus to produce his invention? Whereas, in truth, Mr. Walter knew nothing of Mr. Kœnig till after his invention had been completed. He was merely the first newspaper proprietor who purchased from the Patentees the Printing Machines long before invented by Mr. Kœnig. Of these patentees I was one, and as I am now the sole survivor, it devolves upon me to contradict any erroneous statements and unfounded pretensions. I feel this to be the more necessary, as already the misstatements of The Times are circulated, with additions and exaggerations, in other journals.

* To me this story appears not a little extraordinary :-the " discovery of the retreat" of Messrs. K. and B.! who were every day to be found stperintending our factory in Whitecross Street,-R. T. 
Thus, in an article in the Mechanics' Magazine for Sept. 18, copied into the newspapers, I find the following passage :-

"No sooner were presses made of iron, than the idea occurred of working them by steam; and the first to welcome the new and happy thought was the proprietor of a journal which stood in instant need of some such powerful auxiliary to enable him to keep pace with a circulation unexampled in the history of the press, and who, without it, would most assuredly never have been able to attain to that prodigious influence which for many years past has at once astonished and awed the world. Koenig, the ingenious inventor of the steam-press*, found in the proprietor of The Times his natural and best possible patron. With the liberal aid of the late Mr. Walter, he produced a machine of somewhat gigantic size, but nevertheless possessing a completeness of design and purpose which cast all other surface printing-presses into the shade."

And again-

"The steam-press has given occupation to many thousands, who, but for its introduction, would have been standing idle, and who ought, one and all, to bless the memory of $\mathrm{Mr}$. Walter for enabling the inventor to work out his ideas, and perfect his great and glorious undertaking."

Now the whole of this is a fable. Mr. Walter was no "natural and best possible patron" of Mr. Konig's,-gave him no "liberal aid in producing his machine," nor did anything whatever to "enable him to work out his ideas." These had all been worked out long before; patents had been taken out, a machine had been made, and was in operation on the premises of the Patentees, before ever Mr. Walter, or any other newspaper proprietor, was applied to and invited to adopt it. Mr. Perry of the Morning Chronicle declined, alleging that he did not consider a newspaper worth so many years' purchase as would equal the cost of machines. Mr. Walter, "being a cautious man of the world," but enterprizing, "it being," as his biographer says, " bis habit in the game of life never to throw away a chance," when he had fully satisfied himself by seeing that the invention was accomplished, and in effective operation, consented to give an order for two machines, for the cost of which he paid us a certain sum, and a rental according to the number of copies printed; and this rent we received, until it was commuted for a sum agreed upon.

I do not mean to charge the writer in the Mechanics' Magazine with any intentional misrepresentation. He has evidently been misled by the articles in The Times, which though they do not directly assert all that he has inferred from them, yet they imply as much. Thus a story gains in the telling,

- Mr. Kœnig's invention is very inappropriately designated by the terms "steam-press,", and " the working of iron presses by steam." Its construction is wholly independent of the motive power employed. 


\section{On the Invention of Mr. Kœnig's Printing Machine.}

till the most vague and unfounded suggestions, if uncontradicted, are assumed as indisputable facts; and it would be recorded that if Kœnig was the Gutemberg of the new discovery, Walter was at least the Faust or Schœffer of the affair, or rather, both in one.

I am convinced that $\mathrm{Mr}$. Walter, were he living, would disclaim the pretensions that have been made in his name: and indeed he has done so in the announcement which appeared in The Times, Nov. 20, 1814, the day on which that journal was first printed by the machines, and which contains the following passage:-

"That the completion of an invention of this kind, not the effect of chance, but the result of mechanical combinations methodically arranged in the mind of the artist, should be attended with many obstructions and much delay may be readily admitted. Our share in the event has indeed only been the application of the discovery, under an agreement with the patentees, to our own particular business."

"The time for effecting the great revolution in the art of printing," says Mr. Walter's biographer, "did not arrive till the year 1814." Now it was in 1809 that, together with the late Mr. George Woodfall, I joined Mr. Kœnig and Mr. Bensley in taking out patents*, the machine being even then so far advanced as to satisfy us as to the prospect of success, and to enable us to have the specifications drawn up. Koenig had gone on with Bensley, to whom I had recommended him some few years before, up to the year 1809 , when the taking of premises and the purchase of lathes, tools, \&c., and the employing of workmen, with the salaries of Mr. Kœnig and his able and excellent assistant Mr. Bauer, led Bensley to invite us to a partnership in the undertaking. For several years it occupied much of our time and attention, and cost us much money (from which we had no return $\dagger$ ) and much anxiety. Each experiment suggested some improvement, and one improvement led to others, so that additional patents had to be taken out. But with Mr. Walter we had none of us any communication, until, as I have before stated, the machine had been completed and was at work on our own premises.

I have thought it right, under the circumstances, to put on

* One of the four patents bears date March 29, 1810 (See Phil. Mag. vol. xxxv. Ist Series, p. 319). It was taken out in the name of Frederick Konig, and was assigned by articles of partnership to the firm of Bensley, Konig, Woodfall and Taylor.

+ Mr. Kœnig left England, suddenly, in disgust at the treacherous conduct of Bensley, always shabby and overreaching, and whom he found to be laying a scheme for defrauding his partners in the patents of all the advantages to arise from them. Bensley, however, while he destroyed the prospccts of his partners, outwitted himself, and grasping at all, lost all, becoming bankrupt in fortune as well as in character. 
record my own recollections as to the progress and introduction of this invention: and though they relate to transactions which took place from thirty to forty years ago, I believe they are in the main correct, and can be confirmed by documentary evidence.

\section{Proceedings of Learned Societies. \\ CAMBRIDGE PHILOSOPHICAL SOCIETY.}

[Continued from p. 143.]

N the Partitions of Numbers, on Combinations, and on Permutations. By Henry Warburton, M.P., F.R.S., F.G.S., Member of the Senate of the University of London; formerly of Trinity College, A.M.

The use made by Waring of the Partitions of numbers in developing the power of a polynome, induced the author to seek for some general and ready method of determining in how many different ways a given number can be resolved into a given number of parts. On his communicating the method described in article 5 of Section L of this abstract, to Professor De Morgan, in the autumn of 1846 , that gentleman intimated a wish that the author would turn his attention also to Combinations; and such was the origin of the researches which form the subject of the 2 nd and 3rd sections.

\section{On the Partitions of Numbers.}

1. Let $\left[N, p_{n}\right]$ denote how many different ways there are of resolving the integer $\mathrm{N}$ into $p$ integral parts, none less than $\eta$. Then

$$
\left[\mathrm{N}, p_{n}\right]=\left[\mathrm{N} \pm p^{\theta}, p_{n \pm \theta}\right] . . . . .
$$

2. Such of the $p$-partitions of $\mathrm{N}$ as contain $\eta$ as a part, and no part less than $\eta$, are obtained by resolving $N-\eta$ into $p-1$ parts not less than $\eta$, and by adding $\eta$, as a $p$ th part, to every $\operatorname{such}(p-1)$ partition. That is,

$$
\left[\mathrm{N}, p_{n}\right]-[\mathrm{N}, \underset{n+1}{p}]=[\mathrm{N}-\eta, p-1] . \quad . .
$$

3. In (II.), substitute $\eta+1, \eta+2$, \&c. successively for $\eta$. The sum of the results is

$$
\left[\mathrm{N}, p_{n}\right]-\left[\mathrm{N}, p_{n+\theta+1}\right]=\underset{z^{0}}{\mathrm{~S}^{\theta}}[\mathrm{N}-\eta-z p, p-1] .
$$

In this expression, when $\theta=\mathrm{I}^{*}\left(\frac{\mathrm{N}}{p}\right)-\eta$, the term $\left[\mathrm{N}, p_{\eta+\theta+1}\right]$ vanishes, and the formula then becomes analogous to one published anonymously by Professor De Morgan in a paper printed in the fourth volume, p. 87, of the Cambridge Mathematical Journal.

4. In (II.), for $\left[\mathrm{N}, p_{n+1}\right]$ substitute $\left[\mathrm{N}-p \eta, p_{1}\right]$, and transpose

* I $\left(\frac{N}{p}\right)$ is employed to avoid the long phrase, " the integer nearest to and not exceeding $\frac{N}{p}$." 